\title{
'n Greep uit die Ou-Testamentiese wetenskap in Nederland en Suid-Afrika
}

W S Prinsloo

\section{ABSTRACT}

\section{A perspective on Old Testament studies in the Netherlands and South Africa}

This article contains a summary of the papers delivered during the first congress of Afrikaans-speaking and Dutch-speaking Old Testament scholars held in Leiden from 11 to 12 July 1995. The papers present an overview of what is currently being done in the field of the Old Testament in each of the countries.

\section{INLEIDING}

Op 11 en 12 Julie 1995 het daar vir die eerste keer, sover bekend, 'n kongres tussen Nederlandssprekende en Afrikaanssprekende Ou-Testamentici by die Rijks Universiteit Leiden ${ }^{1}$ plaasgevind. Die Faculteit der Godgeleerdheid van dié universiteit het as gasheer opgetree vir die 24 deelnemers. Die Suid-Afrikaaanse verteenwoordigers was: S Abrahams (University of Fort Hare), J Cook (Universiteit van Stellenbosch), F E Deist (Universiteit van Stellenbosch), D Heyns (Unisa), J H le Roux (Universiteit van Pretoria), J A Loader (Unisa), J P J Olivier (Universiteit van Stellenbosch), G T M Prinsloo (Universiteit van Pretoria), W S Prinsloo (Universiteit van Pretoria), S D Snyman (Universiteit van die Oranje Vrystaat), H F van Rooy (Potchefstroomse Universiteit vir Christelike Hoër Onderwys) en $\mathrm{H}$ Viviers (Randse Afrikaanse Universiteit). Die Nederlandse groep het bestaan uit: P C Beentjes (Katholieke Theologische Universiteit Utrecht), W A M Beuken (Katholieke Universiteit Leuven), K A Deurloo (Universiteit van Amsterdam), P B Dirksen (Rijks Universiteit Leiden), C Houtman (Theologische Universiteit Kampen), K Jenner (Rijks Universiteit Leiden), A van der Kooij (Rijks Universiteit Leiden), $\mathrm{H}$ J Leene (Vrije Universiteit Amsterdam), J C de Moor (Theologische Universiteit Kampen), E Noort (Rijks Universiteit Groningen), E J van Wolde (Theologische Faculteit Tilburg) en A S van der Woude (Rijks Universiteit Groningen). 
Aangesien daar slegs ses referate in die loop van twee dae gelewer is, was daar ruim tyd vir bepreking en vir akademiese gesprek. Drie referate is deur Suid-Afrikaners (F E Deist, J A Loader en W S Prinsloo) en drie deur Nederlanders (W A M Beuken, J C de Moor en E Noort) gehou.

\section{DIE REFERATE UIT SUID-AFRIKA}

2.1 F E Deist het in sy referaat ("Literatuur as kultuur: Die teologiese belang van kultuurstudie vir die interpretasie van die Ou Testament”) die stelling gemaak dat die ontdekking van die kultuurbedding van die Ou Testament in die negentiende eeu gelei het tot sowel die opvatting dat die Ou Testament "plagiaat" is as tot die opvatting dat dit "uniek" is. In die twintigste eeu is daar veral aandag gegee aan literatuur- en godsdiensvergelykende studies, wat meestal of op idealistiese of op positiwistiese basis geskied het. Die vraag het ontstaan of hierdie kennis werklik bydra tot die interpretasie van die literatuur van die Ou Testament. Met die opkoms van fenomenologiese en strukturalistiese benaderings tot teksinterpretasie het die kulturele faset van die Ou Testament effens op die agtergrond geraak. Sedert die tagtigerjare is daar egter weer 'n hernude belangstelling: dié keer op basis van 'n materialistiese (ideologies-kritiese) of kultuurantropologiese teorie.

Die referaat van Deist skets hierdie verloop kortliks, stel die ideologie-kritiese en kultuurantropologiese benaderings kortliks aan die orde en illustreer dit aan die hand van die Ehudverhaal in Rigters. Die referaat het afgesluit met kort opmerkings oor die probleme van die benadering, die vrae wat dit aan die gereformeerde sistematiese teologie stel en die belang daarvan vir die kontekstuele interpretasie van die Skrif in Afrika.

2.2 J A Loader het in sy referaat ("Die moontlikhede van Elihu. Wat in Suid-Afrika gedoen is/kan word") die behandeling wat die Elihuredes (Job 32-37) gedurende die afgelope drie dekades in Suid-Afrika ontvang het, onder die loep geneem, maar ook 'n eie voorstel gemaak oor wat daarmee gedoen kan word.

Drie voorbeelde is gebruik om drie eksegetiese tradisies en hul invloed in Suid-Afrika aan te toon. Aandag is gegee aan:

(a) hoe Elihu deur 'n klassiek gereformeerde bril (weliswaar 'n Nederlandse bril, maar een wat die Suid-Afrikaanse son outomaties akkommodeer, naamlik J H Kroeze) daar uitsien, 
(b) die hantering van die Elihuredes deur A van Selms (met verwysing na die Nederlandse agtergronde daarvan), en

(c) die tipies Suid-Afrikaanse "immanente" hantering van die Elihuredes soos dit veral in die sewentiger- en tagtigerjare gebloei het (met L C Bezuidenhout as voorbeeld).

Loader het gepoog om die eiendomlike van die drie tradisies te illustreer aan die hand van hoe elk die spesifieke digwerk eksegetiseer. Ten slotte is metodiese purisme van die hand gewys en aan die hand van die Elihuredes betoog dat die hermeneutiese proses in elk geval van meet af elemente bevat wat eie is aan verskillende perspektiewe. Daar is gepoog om die teologiese betekenis hiervan an te dui.

2.3 W S Prinsloo het in sy referaat ("Psalm 97: Almal moet bly wees, want Jahwe is koning") homself eerstens geposisioneer ten opsigte van die Suid-Afrikaanse Ou-Testamentiese toneel en het vervolgens 'n teks, naamlik Psalm 97, geneem om die benadering wat hy voorstaan te illustreer. Aan die een kant word die gedagte dat daar so iets bestaan soos die objektiewe lees van 'n teks of die een regte betekenis van 'n teks, afgewys. Aan die ander kant word gewaarsku teen die ander uiterste, naamlik dat 'n teks 'n oneindige aantal betekenisse sou hê. $\mathrm{Na}$ 'n oorsig van die Forschungsgeschichte van Psalm 97 - wat onder andere die problematiek van die sogenaamde koningspsalms en die vraag na die Gattung insluit - is 'n uitvoerige en selfstandige analise van die psalm gedoen waarin die klem op morfologiese, sintaktiese, semantiese en stilistiese aspekte val. Uiteindelik is die volgende konklusie ten opsigte van die psalm gemaak: Hoewel Psalm 97 baie van sy inhoud aan die res van die Ou Testament ontleen, vertoon dit tog 'n samehangende geheel en sou daar van 'n kunstige gedig gepraat kon word. Ou, geykte stof is op 'n kreatiewe manier geherinterpreteer en in 'n nuwe, unieke vorm gegiet. Die gedig vertoon deurgaans allerlei literêre tegnieke en poëtiese konvensies.

Psalm 97 is dus 'n geïntegreerde geheel en 'n ingewikkelde netwerk van verhoudinge waarin alles meewerk tot een oorkoepelende doel, naamlik om die leser/hoorder te oortuig dat Jahwe koning is. Op grond van die klem op die koningskap van Jahwe en in die lig van die hele psalm, sou gesê kon word dat Psalm 97 'n oorredende teks is. 
3.1 Die uitgangspunt van W A M Beuken se referaat ("Jesaja 30: Een profetie overgeleverd door middel van twee paradigmata") is die vraag of Jesaja 30 na inhoud en literêre opset 'n sinvolle eenheid vorm. Soms word die eenheid van Jesaja 30 betwyfel indien 'n mens net let op die volgorde van 'n oordeelsaankondiging teen Juda, 'n heilsbelofte vir Sion en 'n strafgerig teen Assirië. By nadere ondersoek blyk egter dat die Jesajaanse oorlewering 'n profesie van die profeet Jesaja ( $v$ v 1-17) geaktualiseer het deur middel van twee uitbreidings wat gebaseer is op twee paradigmata, naamlik dié van die trektog onder God se leiding ( $v v$ 18-26) en dié van die teofanie op die berg van Jahwe (vv 27-33). Die twee uitbreidings sluit goed aan by die profesie en speel op mekaar in. Die uitbreidings se temas, semantiek en "spreekrichting" is so daarop afgestem dat hulle saam die lyne van die profetiese orakel voortsit. So vorm die terugkeer naa Sion en die bewoning van die land onder God se seën (vv 19-25a) die verwagte vervolg op die algehele vlug en verlatenheid (v 17). Die verskyning van Jahwe op sy eie berg Sion ná die terugkeer na die land toe, vervang selfs dié op Sinai tydens die woestyntog. Die tradisie het die overlewering van die profetiese boodskap voltrek deur dit te plaas in die herkenbare kader van "de grote verhalen", wat vir Israel op sy gang deur die tyd begelei het.

3.2 J C de Moor het in sy voordrag ("Masseben en voorouderverering") aangevoer dat ' $n$ mens oor die algemeen kan sê dat daar in Nederland sedert die dertiger jare nie veel belangstelling vir die godsdiens van Israël bestaan het nie. Dit sou toegeskryf kon word aan die sterk invloed van Karl Barth op die Nederlandse protestantisme. In die laaste dekades is daar egter 'n oplewing van die ondersoek na die godsdiens van Israel te bespeur. Daar bestaan nogtans ' $n$ groot agterstand, wat verklaar waarom die enigste belangrike Nederlandse studie oor die "masseben" - dié van J de Groot - dateer uit 1913.

Met gebruikmaking van materiaal uit Mari, Hatti, Ugarit en Emar, maak de Moor die stelling dat alle opgerigte "stenen" die funksie gehad het om die herinnering aan iets of iemand lewend te hou. Hoewel ook belangrike gode met stèlae vereer kon word, moet die funksie van die "masseben" in die voorouerkultus sterker benadruk word as wat T N D Mettinger dit in sy jongste boek (No graven image?) doen. Die masseba het heel dikwels die nagedagtenis van die voorouer na vore gebring en het die voorouer fisies in die kultus verteenwoordig. Vir die lewende mense was dié klippe, wat dikwels in groepe opgestel was, 'n middel om kontak 
te maak met die geeste van hulle voorgeslagte. Die onderhouding van die voorouerkultus was die verantwoordelikheid van die oudste seun.

Daar is sterk aanduidings dat die anikoniese verering van die voorouers tot by die deuteronomistiese hervormings nie verbode was in Israel nie. In ooreenstemming met die feit dat Jahwe-El van oorsprong self 'n voorvader-God was, "treft men er nog de sporen van aan dat Hij is vereerd in de vorm van aniconische opgerichte stenen".

3.3 E Noort het in sy voordrag ("De val van de stad Jericho: Jozua 6") veral die literêr-kritiese benadering geillustreer. Aangesien Noort 'n groot gedeelte van sy akademiese loopbaan in Duitsland deurgebring het, het hy ter inleiding 'n paar belangrike opmerkings oor die ontwikkeling en verloop van die Ou-Testamentiese wetenskap in Duitsland gemaak. Uitgaande van die kwartet Alt, Noth, von Rad en Zimmerli, wie se posisie en standpunte nie toegelig hoef te word nie, is die verskillende ontwikkelinge van die vakgebied die duidelikste sigbaar by die daaropvolgende generasie wat volgens Noort verteenwoordig word deur die kwartet Koch, Rendtorff, W H Schmidt en Herrmann.

In die lig van die diversiteit van benaderings is dit vir Noort nuttig om na die plek en funksie van die literêre kritiek te vra. Hy illustreer dit aan die hand van Josua 6 , een van die mees komplekse verhale uit die corpus Josua 1-12. Dat die val van Jerigo nooit 'n selfstandige verhaal was nie, blyk uit die "minimale wijze" waarop 'n verbinding met Josua 2 gelê word. Daar is wel verbindingslyne met Josua $1: 3 \mathrm{ev}$ en $7 \mathrm{vv}$ op te merk, maar dit raak nie die kern van die verhaal nie. Daar is wel verskillende visies op die gebeure binne die verhaal self aanwesig. In dié gevalle waarin daar dan ook nog na die rol van die argeologie van Palestina gevra word, word die vraag na die plek en funksie van die literêr-historiese benadering nog meer kompleks. Die vraagstelling van Noort se lesing was of literêrkritiese onderskeidings noodsaaklik is om die plek, die funksie en die doel van die Josuaverhaal voldoende te beskryf, of anders gestel: Watter verlies is daar wanneer daar nie literêr-kritiese vrae gevra word nie?

\section{SAMEVATTING}

Vanweë bekende historiese redes was dit vir baie jare vir die meeste SuidAfrikaanse Ou-Testamentici nie moontlik orn op amptelike vlak met hulle Nederlandse kollegas akademiese wisselwerking te kon hê nie. Akademiese kontak was vir baie jare hoofsaaklik beperk tot kontak tussen individue en was in 'n sekere sin afhanklik van die goedgesindheid van 'n bepaalde 
individu. Van amptelike samewerking tussen vakwetenskaplike liggame en samewerking tussen institute en departemente van universiteite was daar egter weinig sprake. Vanselfsprekend het dié situasie 'n verlies vir die OuTestamentiese wetenskap - veral vir die Ou-Testamentiese wetenskap in Suid-Afrika - veroorsaak. Die situasie moet betreur word veral aangesien die taalaspek akademiese kommunikasie en wisselwerking tussen SuidAfrika en Nederland eintlik moes bevoordeel.

Die kongres tussen Nederlandse en Suid-Afrikaanse Ou-Testamentici - die Nederlanders het Nederlands en die Suid-Afrikaners het Afrikaans gepraat - moet verwelkom word aangesien dit vir twee akademiese wêrelde weer moontlik geword het om amptelik met mekaar in gesprek te tree om sodoende die Ou-Testamentiese wetenskap te bevorder. Die kongres was in alle opsigte 'n sukses. Nie alleen word daaraan gedink om dit op te volg nie, maar allerlei moontlikhede tot akademiese samewerking het hieruit voortgevloei en word verder ondersoek. Die hoë peil van die voordragte het duidelik onderstreep dat dit nie 'n eenrigting verkeer was nie, maar dat die Ou-Testamentici van beide kontinente iets vir mekaar te sê het ten op sigte van hulle vakgebied.

Die ses voordragte wat op die kongres gelewer is getuig van uiteenlopende spesialiteitsrigtings en verteenwoordig 'n verskeidenheid van metodologiese invalshoeke. In dié sin was die kongres 'n spieëlbeeld van dit wat op die oomblik ook op die navorsingsterrein van die Ou Testament aan die gang is, naamlik soveel hoofde soveel sinne. Daar is gewoon nie meer ' $n$ benadering wat as dié benadering of dié metode getipeer kan word nie. Die aspek het veral duidelik na vore getree in die bespreking van die referate. Dit maak kongresse en akademiese gesprek van dié aard egter nog meer noodsaaklik en opwindend.

\section{NOTAS:}

1 Hierdie Leidenkongresberig word opgedra aan oudkollega Carl Borchardt wat vir 15 jaar as boekresensieredakteur van Skrif en Kerk opgetree het en wat ook aan die Rijks Universiteit Leiden gepromoveer het.

Hiermee word dank uitgespreek teenoor die Sentrum vir Wetenskapsontwikkeling (SWO) vir 'n toekenning om die kongres by te woon. Menings wat hier uitgespreek is, is nie noodwendig die van die SWO nie. 